\title{
LARGE INTERNATIONAL FIRMS IN THE OIL INDUSTRY
}

\section{Biplab Dasgupta*}

\section{Introduction}

No discussion on the oil industry is complete without reference to its seven leading firms, which are collectively known as the "seven sisters" or "majors". The main objective of this paper is to analyse the major characteristics of these firms and the implications of those characteristics for both the oil-producing and the oil-consuming countries in an historical perspective as well as in the light of the current oil crisis.

Five of these firms are domiciles of the USA - Standard Oil of New Jersey (or Exxon), Socony Mobil Oil, Standard Oil of California, Gulf Oil, and Texas Oil. Of the other two, one is British (British Petroleum) and the other is jointly owned by British and Dutch interests (Royal Dutch/Shell). A Fręnch company, called CFP, is of ten described as "the eighth major". In addition to these firms, three other types of firms operate in the world oil market: (a) the "minors", mostly US international companies which are quite large by almost any other standard, except that of the oil industry, (for example, Philips, Standard Oil of Indiana, Occidental); (b) the state-owned companies like Kuwait National Oil Company; some of them, for example ENI, operate as international firms like "minors"; and (c) oil firms of East European countries.

Oil-importing countries do not constitute a homogeneous group. For example, the USA is the largest oil-producing country in the world, but because of its high level of demand for oil, it is a net importer. Some of the oil-importing countries (like UK, Holland or USA) are to varying extents closely associated with oil-producing interests through the operations of the large international oil firms which are domiciled there. ${ }^{1}$ Furthermore, one needs to make a distinction between rich and poor oil-importing countries.

\footnotetext{
* Biplab Dasgupta is a Fellow of the Institute.

3 For a detailed account of the advantages which accrue to the mother countries by way of foreign exchange earnings and access to an important raw material, see Michael Tanzer, The Political Economy of International Oil and the Underdeveloped Countries, London, 1969.
} 
This paper is divided into three parts. In section 2, we will examine the main characteristics of the large international firms; section 3 will briefly cover the current oil crisis in an historical perspective. In section 4 we will examine the future role of these firms in the oil-producing and oil-consuming countries.

\section{Main Characteristics of Large International Firms in Oil}

The four main characteristics of these firms are that they are:

(a) large, (b) multinational, and (c) vertically integrated organisations operating in an (d) oligopolistic market.

\section{Large}

Their vast size and financial resources enable the majors to enter into costly, high risk, capital intensive ventures, like finding oil in the North Sea or Alaska. Very few firms outside the oil industry would have the financial resources to commit such long-term massive investment or to maintain such an enormous budget on $\mathrm{R} \& \mathrm{D}$ as the major oil firms do. Their research activities also help to maintain their technological superiority over non-major rivals. Moreover, very few countries of the world possess the resources, the skilled manpower and the intimate knowledge of the industry and the world market to bargain on equal terms with these mammoth entities. ${ }^{2}$

\section{Multinational}

The "multinational" character of these firms has many interesting implications. Because these firms are multinational, their activities often give rise to serious conflicts between their own global objectives and the national objectives of the host governments. The history of the oil industry is full of many such conflicts. For the oil companies, what matters most is the aggregate profit over all their operations and covering all the countries in which their affiliates and associates are functioning. On the other hand, the national governments are interested in increasing their own revenues from oil exports; or if they are importers and poor, their main concern is to

2 For details about their activities see Edith Penrose, The Large International Firm in Developing Countries: The International Petroleum Industry, London, George Allan \& Unwin, 1967. 
minimise the cost of oil imports through refinery construction, package deals with better prices and terms, and some investment in exploratory activities. Sometimes the national interests of the host governments coincide with the international objectives of those oil firms, sometimes they do not. The following are two typical examples where their interests do not converge:

(a) the amount of crude oil to be extracted from the oilfields of a particular country by a multinational company, which owns oilfields in many countries, depends on a large set of factors, such as the overall crude oil needs of that company, the ownership structure for that particular oilfield (whether it is wholly owned or jointly owned with the government or other companies), as well as the cost, quality and the location of such crude. ${ }^{3}$ The amount which the oil company would decide to lift may not agree with what the government of the country would want. The latter may want more (to earn more revenue) or less (to conserve its depleting resources) than the companies would consider appropriate on the basis of their global activities. Some of the recent examples of such conflict of interests is related to the practice of oil companies to acquire concession rights on a prospective oil-bearing area in order to keep off the potential competitors, but with no immediate intention of exploring and producing oil from that area, since its requirements are already being met at a cheaper cost from other sources. ${ }^{4}$ There are also instances as in the case of Iraq in the 1960s - where the consortium of oil companies may penalise a host country by offtaking a smaller than usual amount in the event of serious disagreements between them ;

(b) conflict of interests may also exist over refining crude oil. Many oil importing countries aspire to be self-sufficient in refinery products in order to minimise costs of imported oil. The conflict arises because the interests of the oil companies may best be scrved

3 Edith Penrose, "Vertical Integration with Joint Control of Raw Material Production", Journal of Development Studies, April 1965, pp. 251-268.

4 Biplab Dasgupta, The Oil Industry in India - Some Economic Aspects, Frank Cass, London, 1971, pp. 223-231.

5 For details, see Edith Penrose, The Large International Firm in Developing Countries, op. cit. 
by building fewer and bigger refineries (subject to the constraint of transport cost from the refinery to the consumption points), thereby reaping economies of scale and being flexible enough to consume various types of crude and to produce a varying range of output$\operatorname{mix} .^{6}$

One implication of this "multinational" character is that conflicts between the national governments and oil companies become matters of international diplomacy and involve the foreign offices of their mother countries. ${ }^{7}$ A good example of this was the international political crises following the nationalisation of the Iranian oil industry by Mosadeq in 1951; when both the British and the US governments used their diplomatic influence over other countries to block successfully the exports of Iranian oil, which eventually led to the violent overthrow of the Mosadeq government in 1954. More recently, in the 1960s the threat of stoppage of US aid was applied against Ceylon and Peru when they nationalised the oil companies owned by US firms. ${ }^{8}$ In return for this support, the major oil companies maintain close relationship with the foreign offices of their mother countries, and help them in their dealings with the governments of the countries where the companies operate. ${ }^{9}$

Oil being an important material for both war and peace-time economy, the governments of the mother countries of the "majors" are very keen to retain their access to oil reserves through the latter. There are often conflicts between different mother countries for influence in the oil producing areas, which then leads to the sort of compromise which is reflected in the ownership structure of several oil consortia in the Middle East. Iraq Petroleum Company, whose ownership is shared by British (British Petroleum 23.75\%), DutchBritish (Royal Dutch/Shell 23.75\%), French (CFP 23.75\%), and

6 Dasgupta, op. cit., pp. 65-68, 113-117.

${ }^{7}$ George Lenezowski, Oil and State in the Middle East, New York, 1960.

8 Penrose, op. cit.

9 Tanzer, $o p$. cit., for example, the Vice-President of Standard Oil of New Jersey said in 1966, "Our government has the interest, as well as the means, to promote US investments abroad in furthering the objectives of our foreign policy". For this and similar quotations, see Zuhayr Mikdashi, The Community of Oil Exporting Countries: A Study of Governmental Co-operation, London, 1972. 
American (Standard Oil of New Jersey and Socony Mobil jointly $23.75 \%$ ) interests, as well as an independent (Gulbenkian $5 \%$ ), is a good example of the diplomatic involvement of several great powers in the oil industry of the Middle East.

Vertically integrated

A main characteristic of these large, international firms is their participation in all stages of activities in the oil industry, from exploration, development and extraction of crude oil to transporting, refining and marketing. This, combined with the multinational character of their operations, has several important consequences for the economies of the countries in which they operate. ${ }^{0}$

A major consequence of vertical integration is that a great deal of commercial and trading transaction which takes place between countries is no more than intra-company transaction between the affiliates of the same mother company. Hence, the prices charged and paid for are not the results of "arm's length deals", but are internal bookkeeping prices, or transfer prices involving various branches of the same corporate body. For example, when the crude-producing affiliate of Exxon in Saudi Arabia sells crude to the Exxon refinery at Bombay, from the point of view of the latter (assuming no interference from the government), the amount purchased is not dependent on the quoted price.

A corollary of the above is that what matters most to a vertically integrated firm is the overall profit from all its operations, and not the "profits" shown by its individual constituents. It is possible for such a firm to manipulate the transfer prices for inter-affiliate transactions, and thereby to produce bookkeeping profits or losses for individual affiliates which are consistent with their overall global objectives. In fact, the tendency for the vertically integrated oil firm is to show a higher profit in crude production, because the latter usually receives more tax concessions than other activities, and to show a smaller profit or even losses from downstream activities like refining or marketing. ${ }^{11}$

10 J.G. McLean and F.W. Haigh, The Growth of the Integrated Oil Companies, 1954.

11 Penrose, op. cit.; see also, "Profit Sharing between Producing Countries and Oil Companies in the Middle East", Economic Journal, June 1959. 
The profits or losses shown by the affiliates of such a firm for production, transportation, refining and other activities in various countries have no particular significance to the firm concerned, excepting as a means of tax avoidance and maximisation of aggregate profit over all activities. ${ }^{12}$

On the other hand, the way such prices and profits are shown is highly significant from the point of view of the governments of the countries in which they operate. The larger the price at which the crude producing affiliate of Company $\mathrm{X}$ in Country A sells crude to its refining affiliate in Country $\mathrm{B}$, the higher becomes the foreign exchange cost of oil imports and the lower becomes the government's tax revenue on profit in refining in Country B.

It was not until the 1960 s that the governments of the poor oil importing countries came to understand the implications of vertical integration for crude oil prices which they paid. For example, even in 1961 the government of India was not aware that the refineries in India, their crude suppliers in the Middle East and a whole range of intermediate dealers who stood between the refinery and the crude supplier, were all merely parts of one and the same corporate organisation. ${ }^{13}$ One of the reasons for having so many intermediate organisations was to maintain secrecy about oil prices.

\section{Oligopolistic}

The oil industry is a classic example of an oligopolistic market with seven dominant oligopolistic firms and a large number of smaller firms on the fringe. In the "golden days" of the oil cartel, about four-fifths of crude production, refining and marketing was controlled by the "majors". Even in 1960, the percentages were 84, 74 and 70 respectively for these three main activities. ${ }^{14}$ Even these figures underestimate their influence on the market, since many of the non-major companies are associates of "majors" and are dependent on them for crude supply or for marketing of crude oil or products.

\footnotetext{
12 Penrose, op. cit.

13 Government of India, Report of the Oil Price Enquiry Committee, (Darule

Committee), 1961.

14 Penrose, op. cit.
} 
The four basic ingredients of the oligopolistic behaviour in the oil industry are as follows:

\section{(a) World Parity Pricing System}

This is a simple, easily understood, basing point price formula which is jointly adopted by the oligopolists. Until 1945, the US Gulf was the basing point, and the price of oil anywhere in the world was fixed by adding transport costs from the US Gulf to that consumption point, irrespective of where the oil actually came from. This formula was followed, even when no oil was imported from the USA by a consumption centre, in order to minimise disputes about prices between the oligopolists and the consequent risks of a price war. One consequence of this price policy, from the point of view of many oil consuming countries, was that they did not benefit from their possible proximity to oil producing areas, since for the purpose of price fixation it was only their distance from the US Gulf which mattered. For example, the price of oil produced in Burma was cheaper in London than in Calcutta (which was 6,000 miles nearer to Burma) because London was closer to the US Gulf. ${ }^{15}$

After 1945, the Persian Gulf was made the second basing point for the Eastern Hemisphere market. By mutual consent, the "majors" now declared the same "posted prices" fob Persian Gulf for crudes of different variety and a wide range of oil products; and these were taken as bases for price fixation in the consumption centres. Even during the 1960s, the years of oil surplus when the prices of crude oil and products declined, the fob Persian Gulf posted prices continued as the base from which discounts in percentage form were deducted.

At one time, the "majors" used to cite the fact that the oil prices were the same everywhere as evidence that the oil market was "perfectly competitive"; while the reality was (and even now is) that the dominant oligopolists strictly adhered to a commonly-agreed price formula in order to minimise the risks of price wars among themselves.

15 Dasgupta, op. cit., chapter 4. See also H.J. Frank, Crude Oil Prices in the Middle East: A Study in Oligopolistic Price Behaviour, 1966. 
(b) Market-Sharing Arrangements

The history of the oil industry contains a number of explicit, written, market-sharing agreements between the oligopolists. Sometimes markets were divided up territorially (as in the 1909 agreement), sometimes by percentages (as in the 1928 "as is" agreement), and at other times by a combination of percentage shares and absolute amounts in a specific market (as in India during 1905-1928). A series of agreements were drawn up during the 1930s to regulate the distribution to the rest of the world of Soviet and Rumanian oil, which were not controlled by the "majors", without disrupting the "world price structure". Since the 1940s, written agreements are unknown, because of the fear of US anti-trust legislation, but the behaviour of the "majors" in this respect is influenced by the unwritten code of conduct of the oil industry against encroachment into each other's territory.

\section{(c) Price Wars}

As distinct from price competition, price war results in reduced prices only for a short period and, more often than not, is followed by the restoration of prices to the pre-price war level. Like the price formula and market-sharing agreements, price wars were an interesting feature of the oil industry up to the Second World War. A price war was usually initiated by a company which was dissatisfied with its market share, and was used as a weapon to force its rivals to accept a redistribution favourable to the company initiating the price war. $^{17}$

In many cases, price wars are also initiated when it is thought that some of the provisions of a previous agreement have been violated by a rival (e.g. the price wars of 1909, 1911, and 1928). There was a tendency for these price wars to spread to many markets, and these "world price wars" caused serious financial losses to all the oligopolists. The 1928 "as is" agreement was an attempt to stop these costly contests, and, since then, excepting for rare instances of very short-term and highly localised price wars in the petrol trade,

\footnotetext{
16 Dasgupta, op. cit., chapter 4.

7 Dasgupta, op. cit., chapter 4.
} 
price wars between the oligopolists have become a rare phenomenon. Not that competition between them has been completely eliminated, but these usually take the form of non-price competitions, except when selling crude to independent refineries; but even in this case, prices are accompanied by varying credit facilities and freight rates which make them non-comparable. ${ }^{18}$

Since 1928, most of the price wars have been fought between "majors" collectively on one side, and the newcomers to the oil trade. Before 1959, the competition of "independents" was localised because of the smallness of their organisations and the virtual absence of non-major sources of crude oil in the Eastern Hemisphere. The "majors" took part in these price wars in order to bring the independents to heel, and succeeded in either eliminating them from the market, or in forcing them to become appendages to their corporate entities through long-term supply arrangements. Since 1959, such competition is no longer localised with the entry into the market of a number of big independents, such as Philips, ENI, Standard Oil of Indiana, and Occidental. ${ }^{19}$

\section{(d) Organisational Interdependence}

Apart from explicit or tacit pricing or market-sharing arrangements between themselves, the oligopolists also jointly own a number of important enterprises in the oil industry. In the marketing and refining sectors many familiar names are found like Caltex (jointly owned by Standard Oil of California and Texas Oil), Burmah-Shell (jointly owned by Burmah Oil, an associate of British Petroleum, and Royal Dutch/Shell), Standard-Vacuum (jointly owned by Standard Oil of New Jersey and Socony Mobil, although the partnership was dissolved in the 1960s). But more important are crude producing organisations, like Aramco of Saudi Arabia (jointly owned by four US “majors"), Kuwait Oil Company (jointly owned by British Petroleum and Gulf Oil), Iranian Consortium (where the seven "majors" together own 79\%, CFP 6\%, and US independents 5\%), and the crude producing organisations of Iraq, Qatar, and Abu Dhabi (where four "majors" and CFP together own 95\%, and the rest is

18 Ibid.

19 Ibid. 
owned by a group of American independent companies), where the major companies are jointly involved. In addition there are several long-term supply arrangements (e.g. between Royal Dutch/Shell and Gulf Oil, under which the latter supplies its entire share of Kuwait oil to the former) and crude and product swapping arrangements in order to iron out localised surpluses and deficits of the individual companies without having to arrange long distance transportation.

As the discussion in section 3 will show, the oligopolistic dominance of the oil market by the "majors" weakened after 1959 . But until then, they were virtually the only suppliers of crude and oil products in the world outside the USA and the communist countries. And as long as they maintained a common front against other competitors and the governments of the oil consuming countries, it was not easy to argue with them about prices, or to induce them to build refineries where this was not in conformity with their own interests, or to plan for a national self-reliant oil industry. Not only that, they were hostile to newcomers in the oil industry; the "majors" were in the habit of threatening immediate stoppage of oil supply if the governments of consuming countries attempted to follow a policy which would make them less dependent on "majors". An example of this was the refusal of the "majors" to refine cheaper crude from the Soviet Union in 1960 in Cuba and India, and another example was their threat to close down their business in India in the following year when the government insisted on a reduction in product prices.

\section{The Historical Background to the Current Oil Crisis}

The history of the oil industry can be conveniently divided into the following three phases in terms of the role of the large international firms :

(i) the period until 1959 when the oligopolistic domination of the world market by the "majors" was virtually complete;

(ii) the $1960 \mathrm{~s}$ when many new competitors arose in the oil market, producing an excess of supply over demand for oil; an era of declining oil prices, which led to the formation of the Organisation of the Petroleum Exporting Countries, (OPEC); 
(iii) the 1970 s when the demand-supply conditions were reversed and prices increased; OPEC became stronger, pushing the major companies into the background in oil negotiations.

One of the important factors in causing this change was the re-entry of Soviet oil exports onto the world market in 1958, and on a large scale in 1959. Before 1917, Russian oil was the chief competitor to American oil in the world market. After the Revolution, Russian oil exports virtually disappeared, except for a brief appearance in the late 1920s and early 1930s (one of which caused the 1928 price war between the "majors"), until 1959 when a shipment of Soviet crude oil was sold to a Japanese independent refiner. Very soon, Soviet exports spread to Italy, Germany, France, India, Greece and other countries, and everywhere these were sold at a price lower than world parity price, and often as part of a package deal involving other products under terms favourable to their partners. ${ }^{20}$

A second, and no less important, factor was the emergence of a number of new competitors who succeeded in finding oil in the neutral zone between Saudi Arabia and Kuwait, and afterwards also in Libya. Since they had no ready marketing outlet, these "minors" were prepared to sell their crude at a much lower than prevailing price to the independent refineries of Western Europe and Japan. ${ }^{21}$

Unlike the "majors" who possessed their own marketing outlets, both the Soviet Union (and Rumania, another oil producing country in the communist bloc), as well as the "minors", were also prepared to build refineries in partnership with the governments in order to receive priority over their competitors in supplying crude to these markets. They were also willing to help the governments with exploratory activities as contractors or with a minority share in the crude producing company, terms which were unacceptable to the "majors".

20 Harold Lubell, The Soviet Oil Offensive and Interblock Economic Competition, 1961, (mimeograph).

21 Dasgupta, op. cit., chapters 7 and 8. 
Both of these factors made the oil industry more competitive, particularly from the point of view of the oil consuming countries, who were now presented with many alternative sources from which they could buy oil. Inevitably, the world parity prices crumbled; in some markets, crude was being sold at prices $30-40 \%$ below fob Persian Gulf "posted prices". "Only fools and affiliates pay posted prices", was the popular joke of the time in the oil industry; but even the affiliates were finding it increasingly difficult to pay full "posted prices" because now the governments of the oil consuming countries were more aware of the changed conditions of the world oil industry.

The "majors" were, as a result, forced to reduce "posted prices" in order to meet this competition. But this led to serious conflicts with oil producing countries, who had been eligible since the early $1950 \mathrm{~s}$ to a half share in the profits from oil, and the decline in oil prices meant for them a lower oil revenue per barrel of oil sold. OPEC was formed in 1960 with the primary objective of halting this decline in oil prices, and succeeded in its aim to stabilise the "posted prices". What this meant in effect was that for the purpose of calculating the tax revenues of the governments of oil producing countries, "posted prices" (which were pegged at their 1960 level) were used as the base; but in practice the oil companies were selling oil at prices which were lower than "posted prices". In other words, while theoretically the profit from oil was split equally between the companies and the governments, in practice, because the realised prices were below posted prices, the host countries received more than half the actual profit. ${ }^{22}$

Two other objectives of OPEC were (a) to induce increases in oil prices, on the grounds that the fob Persian Gulf price of crude was a small proportion of the price the ultimate consumers paid for oil; and that while the prices of industrial goods had been increasing over time, the oil prices had remained at a very low level for many years; and (b) to secure a greater degree of participation in the oil industries of their own countries. ${ }^{23}$

22 Penrose, op. cit.

23 Based on various papers presented to the World Petroleum Congress during this period. See M. Adelman, World Petroleum Market, 1972. 
Their ability to achieve (a) depended on their success in controlling production. Although some attempts were made towards pro rata allocation of production, it failed during the 1960s. Not all the oil producers were members of OPEC; the Soviet Union was an important outsider. Some of the oil producers like Libya had just begun production, and they were unwilling to accept any prorationing arrangements based on existing production shares of various countries. There were also political problems; Iran could be played against the Arabs, as the "conservative" Arabs (like Saudi Arabia or Kuwait) could be played against the "progressive" Arabs (like Iraq, and after the coup, Libya). More success was achieved with (b), as the state owned oil companies were formed which entered into many joint exploration agreements with "minors".

Realised prices were low and declining all through the 1960s. New oilfields in Libya, Nigeria, Algeria and Abu Dhabi sustained the condition of an excess of supply over demand, and some experts notably Maurice Adelman of MIT - confidently forecasted a price of one dollar per barrel of crude by the 1970 s. Adelman's argument was simple; the production cost of oil (at 8 to 20 cents per barrel) was too low in relation to the market price of $\$ 1.30$ to $\$ 1.60$, and he expected that further competition would bring down the latter to a level nearer the "floor price". He recognised that the oil market was not that competitive, and the growing pressure of the OPEC for higher prices, but thought that the latter would not succeed in uniting and controlling production to effect such price increases. ${ }^{24}$

The changed situation in the 1970s has been described in detail in the other papers in this number. The question to ask is, how was it possible for the crude oil prices to increase from about $\$ 1.28$ for $34^{\circ}$ $\mathrm{API}^{25}$ in 1970 to $\$ 11.65$ per barrel after October 1973? One reason for this is the current fear that oil reserves will be exhausted in another 35 to 40 years. This fear may not be well founded - the "proved" reserves are usually conservative estimates, the "probable"

24 M. Adelman, op. cit.

25 API is an inverse measure of the specific gravity of crude oil - the lighter the oil, the higher the API reading. Lighter crudes enjoy a price differential based on gravity; for example, during the 1960 s it was $2 \$$ per degree API. 
reserves are quite high, and there are possibilities of abundant supplies of non-conventional oil from tar sand, shale and coal. It is the general experience in the oil industry that periods of optimism about future supplies are followed by periods of unfounded pessimism; while the "proved" reserves continuously increase with further exploratory work. ${ }^{26}$ What is certain, however, is that whereas a number of big new oilfields were discovered during the 1960 s, except for the North Sea, the record of the 1970s has so far not been very impressive, and the production-reserve ratio of most oilfields has been rising. Furthermore, this reduced rate of discovery of "proved" crude reserves has been combined with an accelerated rate of growth in demand, particularly in the US and Japan. The regulation of crude production by Arab oil producers was now possible for three other reasons:

(a) the Soviet exports were no longer an economically big threat, with the increased demand for oil within that country, and politically they have been close to the Arabs, ${ }^{27}$

(b) the contradiction between new and old producers is not so significant now, since countries like Libya, Algeria and Abu Dhabi have reached their peak production levels;

(c) politically the Arabs were never so united as now, particularly after the October 1973 war. What needs to be stressed, however, is that prices began rising in 1970, long before the 1973 war, although the war has no doubt strengthened the political will of the Arabs. Whereas the OPEC's demand for higher prices failed in the 1960s because of its inability to control production, after the 1973 war it has been possible both to increase the price and to regulate production.

Perhaps more remarkable than these price increases is the increasing participation by the governments in running the oil industry. In 1971, Algeria nationalised the oil industry, and Libya nationalised BP. By 1973, the Libyan government had $51 \%$ ownership in other

26 Petroleum Press Service, July 1973, October 1973.

27 Petroleum Economist, June 1974. 
concessions, Nigeria took over $35 \%$ of Shell-BP concessions, and Saudi Arabia, Qatar, Abu Dhabi, Iraq and Kuwait took over 25\% of equity in oil consortia, and made agreements with the oil companies that by 1982 their share would be $51 \%$. In January 1974, the Kuwait government acquired $60 \%$ of ownership in the Kuwait Oil Company, followed by similar negotiating objectives in Saudi Arabia and Qatar. But the most significant was the nationalisation of the Iranian oil industry in 1973 by the same Shah who overthrew Mosadeq and denationalised the Iranian oil industry in 1954.

The situation as it stands in mid-1974 contrasts sharply with that prevailing in the oil industry two decades ago. Crude oil prices are no longer fixed by the "majors", this role having been taken over by the oil producing states. The companies no longer control oil production in the Middle East, and majority ownership has passed into the hands of the governments. Moreover, even in the sphere of marketing where their dominance was decisive in the clash with Mosadeq many oil consuming countries of West Europe and the less-developed world have been busily working out bilateral deals on oil directly with the governments of oil producing countries, by-passing the companies. Whereas their mother country governments were so vigorous in the past in defending company interests in the host countries, and often turned a blind eye on their evasion of tax and anti-trust laws, now these governments are often more concerned with maintaining good relations with, and flow of oil from, the oil producing countries. ${ }^{28}$

What the oil companies are losing in terms of control over the industry is being partly compensated by the lucrative profits they have made because of higher oil prices; most "majors" have increased their profit by $60 \%$ to $100 \%$ over the past year. ${ }^{29}$ Their control over a substantial part of the marketing network and refining capacity would continue to produce good profit figures for them for a long time to come. The nationalisation of their interests has not necessarily jeopardised their access to crude oil; Iran, for example,

28 Petroleum Economist, July 1974, "Companies Under Fire".

29 However, a great deal of this profit has come from the sale of stocks accumulated before October 1973 . 
has agreed to supply crude to the erstwhile members of oil consortia over 20 years. Moreover, where the companies' interests have not been fully nationalised they are continuing to manage the industry; it will take several years before the Kuwaitis, Libyans and Saudis are able to run their own industries independently of the oil companies.

According to one theory, it was Aramco, the US-owned oil consortium of Saudi Arabia, which encouraged its host government in 1973 to press for higher prices; their motive being to gather as much profit as possible from their operation before the eventual nationalisation of the industry. ${ }^{30}$ Some even allege the complicity of the US government with the Sheikdoms in their decision to increase prices, with the objective of making research on non-conventional oil and non-oil substitutes economically viable. ${ }^{31}$ There is no way of testing these theories, but two things are clear:

(i) no-one has ever suggested that the oil companies voluntarily handed over the control of the industry to the oil producing countries; and

(ii) the demand-supply conditions in the 1970s, coupled with the growing stature and effectiveness of OPEC, were the primary causes for oil price increases, although it is not impossible that, once they felt that their days in the Middle East were numbered, the "majors" encouraged OPEC governments to go for further increases.

\section{The Future of the Large International Firms}

What is the future role of the large international firms in the oil producing and oil consuming countries? From the point of view of the existing oil producing countries in the Middle East the "risk-bearing" function of these companies is no longer of much relevance. The element of "risk" involved in many exploratory activities is not that high, and in some of these countries, Saudi Arabia, Kuwait or Abu Dhabi, the production-reserve ratio is too low to encourage a massive programme for exploration. Moreover, at this moment, there is no shortage of internal funds for such activities if these countries decide to go for intensive wildcat drilling. However,

\footnotetext{
30 New York Post, 10 January 1974.

31 Counter Information Services Anti-Report, The Oilfix, Bertrand Russell

Press, 1974.
} 
the oil producing countries are still dependent on the foreign interests in three fields: (a) technology, (b) administration, and (c) marketing. For a long time the major oil companies ignored the local demand for the training of indigenous personnel; the presence of a handful of local personnel in high technical or administrative positions was hardly more than symbolic. It was only during the 1960 s that through the state-owned companies and with the help of international "minors" some progress was made towards the training of local personnel. Even now, although the local personnel are capable of performing the day-to-day routine activities, they lack the confidence and skill to handle breakdowns. The oil producing countries differ between themselves in their ability to run the industry - from Iran, which has a surplus of technical personnel, to Abu Dhabi, which is almost totally dependent on the foreign personnel for high-skilled jobs. With further training of local personnel and a greater freedom of movement of skilled personnel between the oil-producing countries (which is inhibited by political factors, such as the mutual suspicion between Iran and her Arab neighbours), this technological constraint would, one hopes, be removed in future. But even in the short run the technological dependence on the "majors" is not unavoidable. Unlike the situation 15 years ago, today there are many suppliers of technology in the world market, including the "minors", the East Europeans, the Japanese and the companies like ENI, and equity ownership is no longer a price which must be paid to foreign interests for buying technology.

Perhaps more serious than the technological constraint from a long-term point of view is the marketing constraint. Until very recently an overwhelming proportion of the total crude and refinery production passed through the hands of the "majors", who acted as intermediaries between the oil exporting and the oil importing countries. Because they owned many different types of crude, operated refineries with a wide range of product-mix, conducted their business in hundreds of markets with widely varying demand patterns for oil products, owned tanker fleets to carry oil from a large number of producing areas, it was possible for them to balance the demand and supply for different types of crude and products at the world level, if not singly at least collectively through long-term 
supply arrangements and temporary swapping arrangements. In contrast, the governments of the oil producing countries in the world do not own elaborate marketing networks, and because they rely on a limited range of crudes and products, it is not possible for them to satisfy all types of consumers or to meet short-term shortages on surpluses in individual markets. At this moment - with the cloud of oil shortage hanging over the industry - the marketing problem is not so serious; in fact, the buyers themselves are eager to sign up long-term agreements or to bid enthusiastically for crudes of all varieties which are offered for sale. But this condition may not last indefinitely; with further discoveries of oil and the possibilities of technological breakthroughs in producing non-conventional oil and oil substitutes, in future it would be necessary for the oil producing countries to build their own tanker fleet and to strengthen their own marketing arrangements. It is also necessary for various reasons for such marketing activities to be co-ordinated through an agency like OPEC; firstly, because the marketing sector is the stronghold of the large international "majors" and no member country of OPEC would be able to match their strength singlehandedly; secondly, because such co-ordination would make crude supply more flexible from the viewpoint of consumers; and thirdly, because without this co-ordination there is the risk of the member countries following widely divergent pricing policies which are in line with their own individual development programmes.

Coming now to the poor oil importing countries, their future relationship with the major international oil companies can be considered under three separate headings - crude production, refining and marketing.

Contrary to the popular view, the large international companies are usually "risk averters"; which is why an overwhelming proportion of their drilling effort is concentrated on areas with proved oil prospects (like the Middle East) or in or near western large oil consuming countries, which are politically stable from their viewpoint. Poor oil consuming countries with uncertain prospects for oil do not figure highly in their list of priorities. Even when they acquire concessions in those countries and dig a few holes (as Stanvac did in India taking more than ten years to drill ten wells), the primary motive is 
to keep the potential rivals away rather than to find oil. With the changed conditions in the oil industry over the past year it is not unlikely that this attitude of international oil companies towards exploratory work in oil consuming poor countries would somewhat change, in order to reduce their dependence on Middle East crude. But the "political risk" (e.g. nationalisation or the country concerned joining OPEC) of such investment would always be high from the point of view of international companies. This explains the emphasis they place on exploration in Alaska or the North Sea, where the "political risk" is low. ${ }^{32}$

The reluctance of the major companies to invest in exploration in poor oil consuming countries, many of whom are now desperate to find at least some oil within their boundaries, may not be a bad thing from the countries' point of view. Unlike the situation 15 years ago, it is now possible to receive technological help from foreign collaborators without conferring equity ownership on them, and there is little justification for thinking that the latter would be any less successful than the "majors" in discovering oil. The history of the oil industry is full of stories of oil explorers with limited means or experience or both; for example, William Knox d'Arcy, who discovered oil in Iran, was a businessman of modest means, while Occidental, which have been so successful in finding oil in Libya had no previous experience in this industry, and the Japanese oil companies are continuing to find oil without much of either. In a large number of cases, after a small explorer has found oil, he has been bought up by a major company. Leaving aside very highly expensive explorations with most advanced technology, like the North Sea drilling, the success rates of large international firms are not appreciably better than those for the other firms.

The emergence of OPEC countries as a powerful force in the oil industry has opened up new opportunities for the poor oil consuming countries, particularly the possibilities of joint exploratory activities both in OPEC and poor oil consuming countries with the technical help of "minors" or East European countries. From the point of view of the OPEC countries this would

32 Dasgupta, op. cit., chapter 9. 
be a fruitful investment of their surplus funds in an industry with which they are familiar. It would also be politically effective, both in creating goodwill in poor oil consuming countries and in diversifying the investment of their oil revenue. Moreover, if oil is found, it would not be competitive with their own production if produced under their part-ownership. From the point of view of the poor oil consuming countries, whether crude is found in oil producing countries or within their own territories, this would reduce the impact of the new oil prices on their balance of payments.

In the field of refining four of the strongest arguments usually advanced in favour of the participation of international oil companies (both "majors" and "minors") in equity ownership are as follows:

(a) the latter are able to arrange crude supply on a long-term basis; (b) they are better able, because of their wide marketing network, to handle "refinery imbalance", that is, surplus in some oil products (say petrol) and deficits in some others (for example, diesel), which arises because of the divergence between the pattern of demand for different oil products and the output pattern of the refineries;

(c) they are technically and managerially efficient; and

(d) they can provide the necessary capital and foreign exchange for building the refineries from their own resources.

Of these, (a) is now better secured through direct bilateral arrangements with oil producing countries, and, as far as (c) is concerned, indigenous personnel in many poor countries - including India - are now able to run their own refinery, once it is installed. If the refineries are built in collaboration with the oil producing countries, with the arrangement that the latter would provide crude oil and the foreign exchange cost of the project - which is consistent with the OPEC's long-term interest in participating in downstream activities - it would be possible to remove constraint (d) without bringing in the internationals. The constraint (b) is the most difficult to remove in the near future, since neither the oil consuming countries nor the OPEC countries yet possess the wide contacts with many countries with varying consumption and output patterns.

As the above discussion shows, many of the roles which the "majors" 
performed in both the oil producing and the oil consuming countries can now be performed jointly by these two sets of countries independently of the large international firms. For a long time the major multinationals stood between the oil exporting and the oil importing countries and intermediaries. They fixed the prices of crude oil and refined products and arranged their distribution over the whole world. They knew everything there was to know about the oil industry and about the specific requirements and peculiarities of the individual markets, while very few organisations, governments or individuals outside their oligopolistic network were knowledgeable enough to challenge the data they furnished. They decided how much of crude oil to produce from Country A, and how much to sell to Country B, and the governments of these countries, particularly when they were poor and ignorant about the intricacies of the oil business had very little influence over these decisions. There was no possibility of any direct relationship between Countries A and B, by-passing the "majors". This situation has changed over the past 15 years, particularly since October 1973. The major oil companies no longer fix oil prices, and the oil producing countries are now increasingly taking over the role of sellers of their own crude oil through direct negotiations with oil consuming countries. Moreover, they are increasingly participating in the refining and other downstream activities in oil consuming countries. There is no reason why in future, collaborations in the field of the oil industry could not se extended to oil-based industries (like fertiliser) and other activities which are mutually beneficial to both of these two sets of countries.

How are the large international oil firms responding to this changed situation of loss of power to determine prices and of reduced importance as intermediaries and suppliers of crude oil? It is true that the present high prices of oil are not hurting them financially; but more important than that, from a long-term viewpoint, is their loss of control over the industry and the ever decreasing share of ownership of crude oil. A reading of the current literature on oil would point to two alternatives which the "majors" are likely to follow in the future: one, is to find oil in politically safe areas, like the North Sea or Alaska, and the other is to gradually move out of oil and to extend their interests to non-oil and non-conventional oil industries. It is significant that the US "majors" already own $30 \%$ of 
coal reserves and $50 \%$ of uranium reserves in the USA. If their research efforts succeed in making a technological breakthrough in producing oil from shales, tar sand or coal at low cost, the balance of power in the energy sect or would shift from the Middle East towards North America. The current high oil prices - whether provoked by them or not - is helping them in this respect, both by generating high profit which can be invested in costly exploration programmes and by making research in non-oil energy and in non-conventional oil industries financially worthwhile. 